\title{
Effects of Laser Beak Trimming on the Development of Brown Layer Pullets
}

\section{-Author(s)}

\section{Petrolli TG'}

Petrolli OJ'

Girardini LK'

Zotti MLAN"

Baggio RA"

Junqueira OM"

\footnotetext{
Universidade do Oeste de Santa Catarina " Universidade do Estado de Santa Catarina

II' Universidade Federal de Goias
}

\section{-Mail Address}

Corresponding author e-mail address Tiago Goulart Petrolli

Rua Dirceu Giordani 696, Xanxerê, SC Brazil.

Code: $89820-000$

Tel: $\quad$ (+55 49) 3441-7000

Email: tiago.petrolli@unoesc.edu.br

\section{ABSTRACT}

Laser beak trimming is a promising alternative to conventional hot-blade beak trimming as it is less painful and provides better beak uniformity and better animal welfare. In this study, laser vs. hot-blade beak trimming were compared in $400 \mathrm{Hy}$-line Brown pullets between 2-16 weeks of age. At 7 days of age, birds were distributed according to a completely randomized design into two treatments, with 10 replicates (pens) of 20 birds each. Birds and feed offer and residues were weekly weighed to determine weight gain, feed intake, and feed conversion ratio. In weeks 4, 8, 12, and 16 weeks, one bird per experimental unit was sacrificed to measure the development of the heart development, liver, proventriculus, gizzard, small intestine, and bursa. And of the oviduct in week 16. Pullers submitted to laser beak trimming presented higher weight gain and weekly feed intake, and better feed conversion ratio during the evaluated period. There was no influence of beak trimming methods on the development of the digestive organs, bursa or oviduct. Laser beak trimming can be used as an alternative to hot-blade beak trimming of commercial brown layers.

\section{INTRODUCTION}

Despite the undeniable technological advances achieved in the poultry industry, many of the current management practices have been applied for decades and need to be revaluated. One of such practices is beak trimming of layers, which consists in cutting and cauterizing the beak to prevent aggressive behavior (feather pecking) and cannibalism, feed selection and waste, resulting in better flock uniformity (Campos, 1993). However, beak trimming needs to be accurate and requires specific training, as defective trimming may damage the beak, ultimately affecting flock productivity and welfare.

The beak is essentially a touch organ, with extensive nervous supply. It is used for food apprehension, preening, defense, and for the establishment of social hierarchy. This behavior is particularly important in layer flocks, in which submissive individuals are object of feather pecking, leading to cannibalism and consequently lack of flock uniformity. Beak trimming is the most common method applied in commercial egg production to prevent cannibalism.

During beak trimming, the branches of the trigeminal nerve that innervates the beak are damaged. Neuromas develop at the tip of the beak as part of the normal healing process, and later regress. When severe beak-trimming methods are employed, neuromas with sensory corpuscles and nociceptors may persist and exhibit ectopic activity and spontaneous discharges that cause pain (Crespo \& Shivaprasad, 2003).

According to Mazzuco et al. (2006), bird behavior changes during the first weeks after beak trimming as a result of pain. In particular, the time 
spent eating and drinking are reduced. Defective beak trimming negatively affects bird performance because it hinders voluntary feed intake and causes pain during food apprehension (Webster, 2004; Cheng, 2006).

Anatomical changes of the beak influence the feeding behavior of chickens, and consequently, change their intake capacity. As feed particle size influences the development of the digestive organs, particularly of the gizzard, feed intake changes caused by beak trimming may affect the normal development of the digestive organs.

However, when the temperature of the hot blade used for beak trimming is higher than $700^{\circ} \mathrm{C}$, it may cause beak inflammation, and consequently, the growth of an abnormal tissue in this region, called neuroma, which causes pain when birds peck or feed, impairing their performance.

There are several different methods of beak trimming, which can be classified into four major groups: mechanical, hot-blade, electrical and infrared. The most common method applied for beak-trimming in layers is the hot blade. In addition, beak trimming using hot blade is a complex technique, and it often is poorly performed because the workers are not properly trained, and the repetitive movements required may cause ergonomic problems. Therefore, beak-trimming methods alternative to hot blade need to be evaluated in poultry production systems, such as the use of infrared radiation (laser).

Laser beak trimming consists in applying high laser temperature to penetrate the corneal layer of the beak down to the corneum-generating basal tissue, inhibiting its further growth (Dennis et al., 2009). It is commonly performed at the hatchery. Chicks are restrained in brackets that fix the beak, while mechanical fingers hold the head. A small burst of infrared light is focused on the tip of the beak, which slowly softens and falls about two weeks later (Dennis \& Cheng, 2012).

Laser beak trimming is considered a precise and reliable method, as standardizes beak trimming, reduces the hand labor required on farms, and does not cause blood loss, because there is no surgical cutting and tearing of blood vessels. In addition, laser beak-trimming equipment is equipped with a cooling system, which promotes an anesthetic effect on the beak during the procedure, improving bird welfare. These aspects suggest that laser beak trimming may be the best method to apply under commercial settings.

The objective of this study was to compare the effects of infrared laser beak trimming with conventional (hot blade) beak trimming on the performance and the development of the digestive and reproductive organs of growing brown layer hens.

\section{MATERIAL AND METHODS}

The experiment was carried out at the poultry sector of the University of West of Santa Catarina, Xanxerê campus, state of Santa Catarina, Brazil. Birds were housed in a masonry shed, divided into $1.0 \mathrm{~m} \times 2.0 \mathrm{~m}$ pens, equipped with tube feeders and nipple drinkers.

Four hundred female Hy-Line Brown chicks were evaluated between 1 and 16 weeks of age. At 7 days of age, birds were distributed according to a completely randomized design, consisting of two treatments, with 10 replicates (pens) with 20 birds each. Each pen considered as experimental unit. The following treatments were applied: laser beak trimming (one day of age - T1) and conventional beak trimming (hot blade at seven days of age - T2). Laser beak trimming was performed at the hatchery, when birds were one day old, using Nova-Tech Poultry Service Processor (PSP)(Nova-Tech, Willmar, MN, USA), which emits an infrared beam on the tip of beak, causing tissue death and subsequent erosion of the tip around two weeks of age. Conventional beak trimming was performed when the birds were seven days old, using a hot blade at $700^{\circ} \mathrm{C}$ to cut the distal third of the beak ( $2 \mathrm{~mm}$ from the nostrils) and immediately cauterize it.

Birds were fed diets formulated to meet their nutritional requirements for the growing (1-6 weeks) and development phases (6-16 weeks), according to manual of the genetic company. Feed and water were supplied ad libitum throughout the experimental period. Birds and feed offer and residues were weighed at the beginning of the experiment, and at $4,8,12$, and 16 weeks of age (end of the experiment) to determine feed intake, weight gain, and feed:gain ratio.

In weeks 4, 8, 12, and 16, one bird per experimental unit, with body weight closest to the average weight of the pen, was selected and sacrificed for the evaluation of organ development (heart, liver, proventriculus, gizzard, small intestine and bursa of Fabricius). Birds were euthanized according to the animal welfare and euthanasia standards described in the guidelines of CONCEA (Brasil/MCTI, 2013). Birds were killed by cervical dislocation, bled, and immediately eviscerated to determine organ weights relative to body weight. Oviduct length was measured in the pullets sacrificed at 16 weeks of age. 
The obtained results were submitted to analysis of variance, and means were compared by the t-test at $5 \%$ significance level using the statistical program $R$ ( $R$, 2008).

\section{RESULTS AND DISCUSSION}

Performance results are shown in Table 1. In all evaluated weeks, the birds subjected to laser beak trimming were heavier $(p<0.05)$ compared with those subjected to conventional beak trimming with hotblade. This result is consistent with the findings of Dennis \& Cheng (2010), who reported lower body weight in 5- to 35-wk-old layers submitted to hotblade compared with laser beak trimming.

Higher weekly feed intake $(p<0.05)$, total feed intake $(p<0.05)$ and weekly weight gain $(p<0.05)$ were also observed in layers submitted to the infrared beak trimming at all evaluated ages. These data are in agreement with those reported by Marchant-Forde \& Cheng (2010), who obtained higher feed intake up to 10 weeks of age in layers submitted to laser relative to hot blade beak trimming.

In general, changes in feed intake after beak trimming, independently of the method applied or bird age at the time of beak trimming, indicate lack of motivation to search for food as a result of the pain or discomfort caused by the tissue damage and nerve injury, as well as to the mechanical difficulty to apprehend feed pellets due anatomical changes in the beak shape and loss of sensation (Cheng, 2005; Marchant-Forde \& Cheng, 2010). This may be due to the length of the trimmed beak, which is longer when laser is applied compared with hot blade, allowing better feed apprehension, and consequently, higher feed intake. According to Dennis \& Cheng (2012), birds submitted to laser beak trimming present higher weight gain because this technique causes less pain and the shape of the remaining beak allows the performance of natural feeding behavior. Hot-blade beak trimming causes chronic pain, leading to reduced feed intake, and consequently, poor body development (Dennis \& Cheng, 2010). Dennis et al.(2009) compared hotblade and laser beak trimming in brown semi-heavy layers, and did not find any weight gain differences at 30 weeks of age, demonstrating the applicability of laser beak trimming.

Significant performance differences were observed at all evaluated ages (Table 1). The pullets submitted to laser beak trimming presented higher body weight $(p<0.05)$ at all evaluated ages relative to hot-blade beak trimming. These results do not agree with the findings of Marchant-Forde et al. (2008), who did not find any body weight differences between layers submitted to laser or hot-blade beak trimming. However, several previous studies observed reduced development and body weight after hot-blade beak trimming (Blokhuis et al., 1987; Glatz \& Lunam, 1994; Glatz, 2005; Gentle

Table 1 - Performance results of growing and developing brown layer pullets submitted to conventional (hot blade) or laser beak trimming.

\begin{tabular}{|c|c|c|c|c|c|}
\hline Treatment & Weight/bird (g) & Weight gain (g) & Feed intake/bird (g) & $\mathrm{FCR}^{*}(\mathrm{~g} / \mathrm{g})$ & Cumulative feed intake (g) \\
\hline \multicolumn{6}{|l|}{4 weeks } \\
\hline Conventional & $285 b$ & $245 b$ & $489 b$ & $1.99 a$ & $489 b$ \\
\hline Laser & $310 a$ & $270 a$ & $518 a$ & $1.91 b$ & $518 a$ \\
\hline CV (\%) & 2.65 & 6.87 & 5.67 & 7.43 & 5.67 \\
\hline$p$ & $<0.001$ & $<0.001$ & $<0.001$ & $<0.001$ & $<0.001$ \\
\hline \multicolumn{6}{|l|}{ 5-8 weeks } \\
\hline Conventional & $780 b$ & $495 b$ & $1367 b$ & $2.76 b$ & $1856 b$ \\
\hline Laser & $847 a$ & $537 a$ & $1523 a$ & $2.85 a$ & $2041 a$ \\
\hline CV $(\%)$ & 7.42 & 7.45 & 5.97 & 8.23 & 6.26 \\
\hline$p$ & $<0.001$ & $<0.001$ & $<0.001$ & $<0.001$ & $<0.001$ \\
\hline \multicolumn{6}{|l|}{ 9-12 weeks } \\
\hline Conventional & $1272 b$ & $492 a$ & $2011 b$ & $4.08 b$ & $3867 b$ \\
\hline Laser & 1309a & $462 b$ & $2279 a$ & $4.93 a$ & $4320 a$ \\
\hline CV (\%) & 3.49 & 8.34 & 7.62 & 8.23 & 6.82 \\
\hline$p$ & $<0.001$ & $<0.001$ & $<0.001$ & $<0.001$ & $<0.001$ \\
\hline \multicolumn{6}{|l|}{ 13-16 weeks } \\
\hline Conventional & $1574 b$ & $302 b$ & 2224 & 7.36a & $6091 b$ \\
\hline Laser & $1665 a$ & $356 a$ & 2279 & $6.40 \mathrm{~b}$ & $6599 a$ \\
\hline CV (\%) & 3.62 & 7.23 & 5.97 & 9.31 & 7.55 \\
\hline$p$ & $<0.001$ & $<0.001$ & 0.671 & $<0.001$ & $<0.001$ \\
\hline
\end{tabular}

Means followed by different letters in the same column indicate significant differences $(p<0.05)$ by the T-test. 
et al.1982; Gentle et al., 1997). Gentle \& McKeegan (2007) found that male broiler breeders submitted to laser beak trimming presented higher body weight after 14 days of age in comparison with the use of hot blade.

Beak-trimming method significantly influenced weight gain in all weeks evaluated, with higher values $(p<0.05)$ observer in laser beak-trimmed birds (Figure 1). This result is consistent with the findings of Dennis and Cheng (2010), who determined higher body weight in 10-wk-old layers submitted to laser beak trimming. During the period of 9-12 weeks of age, hot blade beak-trimmed birds presented higher weight gain $(p<0,05)$ than laser beak-trimmed ones.

Hot-blade beak trimming caused lower weekly feed intake $(p<0,05)$ and lower cumulative feed intake $(p<0,05)$ compared with laser beak trimming except for weeks 13-16, when similar feed intake was observed $(p=0,671)$. These results are explained by the greater beak regrowth in laser-trimmed compared to hot blade-trimmed birds, indicating that laser beak trimming does not prevent beak regrowth. This finding is in agreement with Roijen et al. (1997), who observed that, at 16 weeks of age, laser beak-trimmed layers presented similar beaks as those no submitted to beak trimming, except for the missing tip. Dennis \& Cheng (2010), evaluating laser trimming of layers, found better feed efficiency due the beak anatomy after trimming. Laser-trimmed beaks were longer and

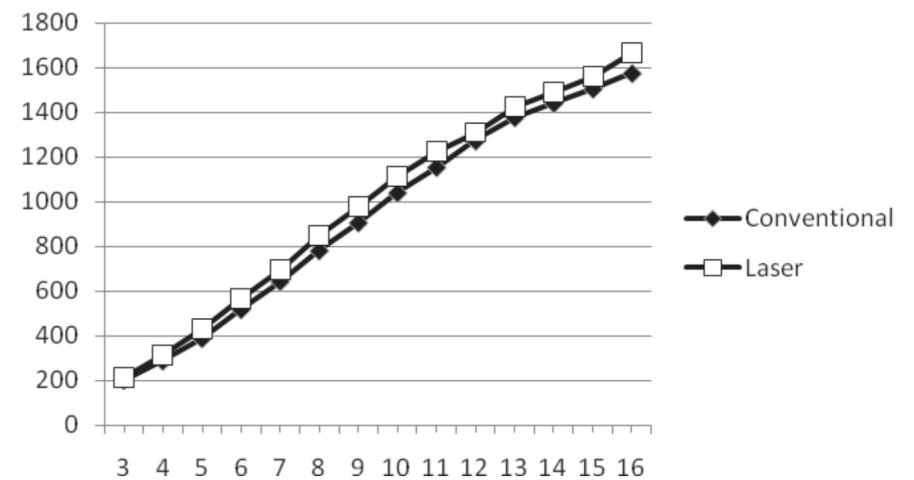

Figure 1 - Weekly growth curve (g) of growing and developing brown layer pullets submitted to conventional (hot blade) or laser beak trimming as a function of age.

more symmetrical than hot blade-trimmed beaks, and were less sensitive to pain during feeding, minimizing the negative effects of beak trimming.

Dennis \& Cheng (2012) reported a gradual erosion of the beak tip, allowing the birds to adapt their feeding behavior as the beak anatomy changes when laser is used. On the other hand, the adaptation of hot bladetrimmer birds is slower, reducing feed intake during the first days post-trimming, consequently impairing normal body development.

Feed intake and body weight are key indicators describing animal performance and welfare after stressful events, such as beak trimming (MarchantForde \& Cheng, 2010). Dennis \& Cheng (2012) stated that laser beak trimming laser improves animal

Table 2 - Relative weight of the digestive organs of growing and developing brown layer pullets submitted to conventional (hot blade) or laser beak trimming.

\begin{tabular}{|c|c|c|c|c|c|}
\hline Treatment & Heart (\%) & Liver (\%) & Proventriculus (\%) & Gizzard (\%) & Small intestine (\%) \\
\hline \multicolumn{6}{|l|}{4 weeks } \\
\hline Conventional & 0.46 & 2.59 & 0.56 & 4.30 & 5.04 \\
\hline Laser & 0.58 & 2.99 & 0.47 & 4.07 & 5.49 \\
\hline CV $(\%)$ & 47.73 & 18.21 & 56.63 & 13.55 & 7.66 \\
\hline$p$ & $>0.050$ & $>0.050$ & $>0.050$ & $>0.050$ & $>0.050$ \\
\hline \multicolumn{6}{|l|}{8 weeks } \\
\hline Conventional & 0.57 & 2.66 & 0.46 & 3.44 & 4.42 \\
\hline Laser & 0.51 & 2.27 & 0.53 & 3.51 & 4.00 \\
\hline CV $(\%)$ & 12.47 & 12.87 & 19.32 & 10.29 & 8.19 \\
\hline$p$ & 0.198 & 0.091 & 0.269 & $>0.050$ & 0.088 \\
\hline \multicolumn{6}{|l|}{12 weeks } \\
\hline Conventional & 0.42 & 1.82 & 0.48 & 2.72 & 3.61 \\
\hline Laser & 0.39 & 1.86 & 0.48 & 2.93 & 3.35 \\
\hline CV $(\%)$ & 19.94 & 12.35 & 22.28 & 9.44 & 10.78 \\
\hline $\mathrm{p}$ & $>0.050$ & $>0.050$ & $>0.050$ & 0.245 & 0.299 \\
\hline \multicolumn{6}{|l|}{16 weeks } \\
\hline Conventional & 0.39 & 1.64 & 0.45 & 2.59 & 3.37 \\
\hline Laser & 0.35 & 2.10 & 0.45 & 3.06 & 3.82 \\
\hline CV (\%) & 22.83 & 25.75 & 14.79 & 13.49 & 11.44 \\
\hline$p$ & $>0.050$ & $>0.050$ & $>0.050$ & 0.088 & 0.118 \\
\hline
\end{tabular}

Means followed by different letters in the same column indicate significant differences $(p<0.05)$ by the T-test. 

of Brown Layer Pullets welfare and reduces hand labor, because birds can be beak-trimmed simultaneously with vaccination in the hatchery. Therefore, it reduces the frequency of bird catching and handling during rearing, which are stressful to the birds. In addition, those authors argue that the automation of the procedure prevents human errors and reduces the variability of the results.

No significant changes were observed $(p>0.05)$ in the relative weight of all digestive organs evaluated (Table 2). This indicates that laser beak trimming does not increase feed intake, and therefore, does not compromise digestive organ development. The obtained results are in agreement with those of Marchant-Forde et al. (2008), who did not observe any differences in liver, heart, spleen, or adrenal gland weights of brown layers submitted to laser or hotblade beak trimming.

Table 3 shows that oviduct length of 16 -wk-old layer pullets was not different $(p>0.05)$ between those submitted to laser or hot-blade beak trimming. These results demonstrate that beak trimming methods did not affect the reproductive development of the pullets. Beak trimming should not delay sexual maturity and subsequent egg production (Marchant-Forde \& Cheng, 2010). Therefore, although both evaluated beaktrimming methods allow similar oviduct development, the higher body weight of laser-trimmed layers suggest that they may sustain egg production longer than hot blade-trimmed layers.

Similarly, no significant differences $(p>0.05)$ were observed in any of the evaluated bursal parameters (absolute weight, relative weight, and diameter; Table 5), indicating that the beak-trimming methods applied in this study do not compromise bursal development in layer pullets.

\section{CONCLUSIONS}

Laser beak trimming at the hatchery can be used as an alternative to conventional hot-blade beak trimming, as it does not compromise the performance, feed intake, or body and organ development of brown layer pullets.

\section{REFERENCES}

Blokhuis HJ, Van Der Haar JJ, Pgkoole PG. Effects of beak trimming and floor type of feed consumption and body weight of pullets during rearing. Poultry Science 1987; 66:623-625.

Brasil. Ministério da Ciência, Tecnologia e Inovação. Diretrizes para a prática de eutanásia do CONCEA. Brasília, DF: MCTI; 2013.

Campos EJ. Comportamento e fertilidade. Avicultura Ciência e Tecnologia 1993;10:16-18.

Cheng $\mathrm{H}$. Morphopathological changes and pain in beak trimmed laying hens. World's Poultry Science Journal 2006;62:41-52.

Table 3 - Oviduct length and bursal parameters of 16-wk-old brown layer pullets submitted to conventional (hot blade) or laser beak trimming.

\begin{tabular}{|c|c|c|c|c|}
\hline Treatment & Oviduct $(\mathrm{cm})$ & Bursal weight (g) & Bursal relative weight (\%) & Bursa diameter (mm) \\
\hline \multicolumn{5}{|l|}{4 weeks } \\
\hline Conventional & - & 1.10 & 0.37 & - \\
\hline Laser & - & 1.50 & 0.50 & - \\
\hline CV (\%) & & 18.5 & 16.7 & \\
\hline$p$ & & 0.346 & 0.331 & \\
\hline \multicolumn{5}{|l|}{8 weeks } \\
\hline Conventional & - & 3.80 & 0.46 & 2.54 \\
\hline Laser & - & 3.00 & 0.35 & 2.34 \\
\hline $\mathrm{CV}(\%)$ & & 12.78 & 12.34 & 7.99 \\
\hline $\mathrm{p}$ & & 0.141 & 0.103 & 0.143 \\
\hline \multicolumn{5}{|l|}{12 weeks } \\
\hline Conventional & - & 4.40 & 0.31 & 2.34 \\
\hline Laser & - & 4.40 & 0.31 & 2.06 \\
\hline CV $(\%)$ & - & 8.35 & 9.28 & 12.04 \\
\hline$p$ & - & $>0.050$ & $>0.050$ & $>0.050$ \\
\hline \multicolumn{5}{|l|}{16 weeks } \\
\hline Conventional & 28.60 & 5.20 & 0.32 & 2.52 \\
\hline Laser & 32.20 & 5.00 & 0.30 & 2.54 \\
\hline $\mathrm{CV}(\%)$ & 12.86 & 14.80 & 15.01 & 10.82 \\
\hline$p$ & $>0.050$ & $>0.050$ & $>0.050$ & $>0.050$ \\
\hline
\end{tabular}

Means followed by different letters in the same column indicate significant differences $(p<0.05)$ by the T-test. 
Petrolli TG, Petrolli OJ, Girardini LK,

Zotti MLAN, Baggio RA, Junqueira OM

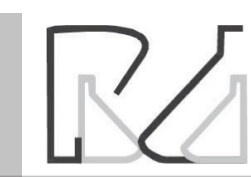

Effects of Laser Beak Trimming on the Development

of Brown Layer Pullets
Cheng HW. Acute and chronic pain in beak trimmed chickens. In: Glatz P editor. Poultry welfare issues: beak trimming. Nottingham: Nottingham University Press; 2005. p.31-49.

Crespo RE, Shivaprasad HL. Developmental, metabolic and other noninfectious disorders. In: Saif YM. Diseases of poultry. 11st ed. Ames: lowa State Press; 2003. p.1055-1056.

Dennis RL, Cheng HW. Effects of different infrared beak treatment protocols on chicken welfare and physiology. Poultry Science 2012;91:14991505 .

Dennis RL, Fahey AG, Cheng HW. Infrared beak treatment method compared with conventional hot-blade trimming in laying hens. Poultry Science 2009;88:38-43.

Dennis RL, Cheng HW. A Comparison of infrared and hot blade beak trimming in laying hens. International Journal of Poultry Science 2010;9(8):716-719.

Gentle MJ, Hughes BO, Fox A, Waddington D. Behavioural and anatomical consequences of two beak trimming methods in 1- and 10-day-old chicks. British Poultry Science 1997;38:453-463.

Gentle MJ, Hughes BO, Hubrecht RC. The effect of beak trimming on food intake, feeding behavior and body weight in adult hens. Applied Animal Ethology 1982;8:147-159.

Gentle MJ, Mckeegan DEF. Evaluation of the effects of infrared beak trimming in broiler breeder chicks. Veterinary Record 2007;160:145148.
Glatz PC. What is beak-trimming and why are birds trimmed? In: Glatz PC editor. Poultry welfare issues: beak trimming. Nottingham: Nottingham University Press; 2005. p.1-17.

Glatz PC, Lunam CA. Production and heart rate responses of chickens beak-trimmed at hatch at 10 or 42 days-of-age. Australian Journal of Experimental Agricculture 1994;34:443-447

Marchant-Forde RM, Cheng HW. Different effects of infrared and one-half hot-blade trimming on beak topography and growth. Poultry Science 2010; 89:2559-2564.

Marchant-Forde RM, Fahey AG, Cheng HW. Comparative effects of infrared and one-third hot-blade trimming on beak topography, behavior, and growth. International Journal of Poultry Science 2008;87:1474-1483.

Mazzuco H, Kunz A, Paiva DP, Jaenisch FRF, Palhares JCP, Abreu PG, et al. Boas práticas de produção na postura comercial [circular técnica 49]. Concórdia: Embrapa Suínos e Aves; 2006.

R Development Core Team. R: A language and environment for statistical computing. Vienna: R Foundation for Statistical Computing; 2008.

Rooijen J, Haar JW van de. Comparison of laser trimming with traditional beak trimming at 1 day and week 6 . Proceedings of the 5th European Symposium on Poultry Welfare; 1997 Jun 7-10; Wageningen. Netherlands: Agricultural University; 1997.

Webster AB. Welfare implications of avian osteoporosis. International Journal of Poultry Science 2004;83:184-192. 